Available online at: http://journal.unj.ac.id

Jurnal

Pensil

Pendidikan Teknik Sipil

Journal homepage: http://journal.unj.ac.id/unj/index.php/ipensil/index

\title{
PROFIL PENGGUNA, TUJUAN PERJALANAN, DAN FAKTOR PENDORONG PENGGUNAAN OJEK ONLINE DI YOGYAKARTA
}

\section{USER PROFILE, TRIP DESTINATION, AND ENCOURAGEMENT FACTORS FOR USING OJEK ONLINE IN YOGYAKARTA}

\author{
Muhammad Iqbal Habibi Kamal ${ }^{1}$ \\ ${ }^{1}$ Universitas Gadjah Mada \\ 1iqbalhaka@mail.ugm.ac.id
}

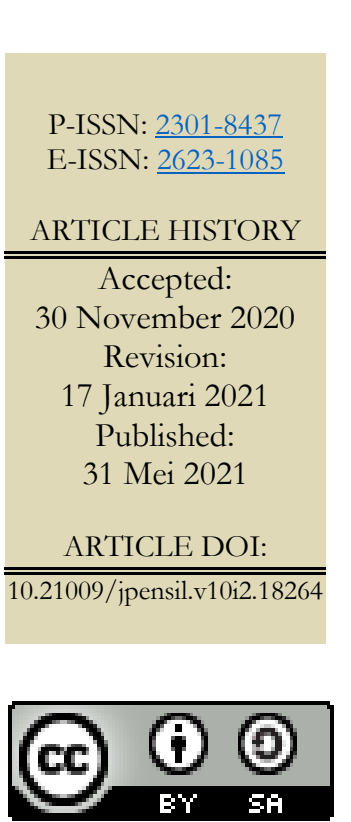

Jurnal Pensil : Pendidikan Teknik Sipil is licensed under a Creative Commons Attribution-ShareAlike 4.0 International License (CC BY-SA 4.0).

\begin{abstract}
Abstrak
Fenomena peningkatan jumlah pengguna ojek online dari tahun ke tahun memunculkan hipotesis bahwa jasa transportasi paratransit ini paling banyak digunakan oleh masyarakat Indonesia pada umumnya. Beberapa penelitian mengungkapkan karakteristik pengguna ojek online adalah lebih muda, berpendidikan tinggi, dan berpenghasilan relatif lebih tinggi. Area Kota Yogyakarta merupakan kota pendidikan yang memiliki kesamaan karakteristik warga, seperti yang telah disebutkan sebelumnya. Penelitian ini bertujuan untuk mendeskripsikan sosiodemografi, tujuan perjalanan, dan faktor-faktor yang mempengaruhi penggunaan ojek online di area Yogyakarta. Metode pengumpulan data adalah wawancara online dengan kuesioner online. Penelitian ini menggunakan metode analisis deskriptif untuk menggali karakter pengguna ojek online, tujuan perjalanan, dan faktor-faktor yang mempengaruhi penggunaan ojek online berbasis sepeda motor. Hasil penelitian ini menunjukkan bahwa perempuan, muda, berpendidikan lebih berpotensi untuk menggunakan ojek online. Destinasi yang paling disukai menggunakan ojek online adalah bandara/stasiun. Di sisi lain, perilaku ramah pengemudi menjadi faktor yang paling disukai pengguna ojek online di Yogyakarta.
\end{abstract}

Kata kunci: Ojek Online, Profil Pengguna, Tujuan Perjalanan, Analisis Deskripsi.

Abstract
The phenomenon of the increasing number of motorycle-based ride-hailing (MBRH)
users from year to year raises the hypothesis that this paratransit transportation
service is the most common use by the Indonesian people in general. A few studies
revealed that the characteristics of the ride-hailing user are younger, highly educated,
and relatively higher income. Yogyakarta City Area (YCA) is a city of education
that has a similar citizen characteristic, as mentioned before. This study aims to
describe socio-demography, trip destination, and factors that affected to use of
MBRH in YCA. The data collecting method is online interviews with an online
questioner. This study uses a descriptive analysis method to explore the character of


the ride-hailing user, trip destination, and factors that are affected using motorcyclebased ride-hailing. The result of this study showed that women, younger, and educated people are more potential to use MBRH. The most favorable destination using $M B R H$ is the airport/station. On the other side, driver-friendly behavior is the most preferred factor for MBRH users in Yogyakarta.

Keywords: Motorcycle-Based Ride-Hailing, Socio Demography, Trip Destination, Descriptive Analysis

\section{Pendahuluan}

Jumlah pengguna ojek online terus meningkat setiap tahunnya. Andriani (2019) menyebutkan bahwa per semester 1/2019, sejak diluncurkan pada tahun 2015 aplikasi dan ekosistem Gojek telah diunduh oleh lebih dari 155 juta pengguna, dengan lebih dari 2 juta mitra pengemudi, hampir 400.000 mitra merchants, dan lebih dari 60.000 penyedia layanan di Asia Tenggara. Metcalfe (2012) dan Silver (2015) menyebutkan bahwa fenomena ini menggeser banyak hal dalam tatanan transportasi perkotaan. Perkembangan pesat pada pelayanan transportasi online juga diprediksikan dapat mengubah perilaku perjalanan masyarakat. Beberapa penelitian menyebutkan bahwa tingginya permintaan perjalanan menggunakan transportasi online dapat berpotensi mengurangi penggunaan kendaraan pribadi dan kepemilikan kendaraan.

Beberapa studi mengemukakan karakteristik pengguna transportasi online yaitu orang-orang yang relatif muda, terpelajar dan berfinansial cukup (Clewlow \& Mishra, 2017; Dias dkk, 2019; Conway dkk, 2018; Grahn dkk, 2020; Sikder, 2019; Young \& Farber, 2019). Sedangkan di Cina, Tang dkk (2020) mengemukakan bahwa $53 \%$ data sampelnya yang merupakan pengguna Didi tidak memiliki pendidikan tinggi. Irawan, dkk (2020) menemukan bahwa faktor usia dan jenis kelamin tidak mempengaruhi penggunaan ojek online, faktor pendapatan berpengaruh positif pada penggunaan ojek online, tingkat pendidikan berpengaruh negatif pada penggunaan ojek online di Jakarta.

Mengutip beberapa referensi tersebut, secara garis besar pengguna transportasi online ialah mereka penduduk berusia muda, berpendidikan serta baik dalam finansial. Studi ini akan mengeksplorasi pengaruh karakteristik penggunaan ojek online dengan studi kasus di Yogyakarta. Penentuan studi kasus di Yogyakarta dikarenakan Kawasan Perkotaan Yogyakarta (KPY) memiliki kemiripan karakteristik seperti yang disebutkan. Sebanyak 110 perguruan tinggi yang terletak di KPY (Badan Pusat Statistik, 2019) menimbulkan adanya potensi pertambahan penduduk mahasiswa yang memiliki karakteristik berusia muda, berpendidikan dan berfinansial cukup.

Berdasarkan beberapa referensi tersebut, studi ini bertujuan untuk mengeksplor dengan menggunakan analisis deskriptif bagaimana karakteristik pengguna, tujuan perjalanan serta variabel laten yang menjadi faktor pendorong penduduk Yogyakarta menggunakan ojek online.

\section{Metode Penelitian}

Penelitian ini bersifat kuantitatif. Pengambilan data dengan metode stratified random sampling yaitu melakukan wawancara kepada populasi yang mempunyai anggota tidak homogen dan berstrata secara proporsional dari setiap elemen populasi dilakukan dengan wawancara menggunakan kuesioner online. Kuesioner dirancang 
dengan beberapa tahapan pertanyaan yang disertai dengan pertanyaan kontrol. Tahapan formulir pertanyaan dimulai dari pertanyaan klasifikasi responden (pengguna atau bukan pengguna), kemudian pertanyaan alasan menggunakan ojek online, lalu pertanyaan tujuan bepergian menggunakan ojek online, dan terakhir pertanyaan berkaitan dengan sosial demografi pengguna. Adapun pertanyaan kontrol ini diberikan untuk dijadikan validitas apakah responden mengisi jawaban dengan baik atau tidak. Contoh pertanyaan kontrol seperti 'isi jawaban 'setuju' pada pertanyaan ini. Target jumlah sampel berdasarkan rumus slovin dengan tingkat kesalahan 5\%. Jumlah populasi di KPY (Kota Yogyakarta, Kab. Sleman, Kab. Bantul) 2.669.981 jiwa (Prov. DIY dalam Angka 2020), maka didapatkan minimal responden yang harus diraih ialah 399,94 $\approx$ 400 responden.

Metode analisis data yang digunakan pada penelitian ini adalah Analisis Deskriptif. Menurut Suryoatmono (2004) menyatakan bahwa statistika deskriptif adalah statistika yang menggunakan data pada suatu kelompok untuk menjelaskan atau menarik kesimpulan mengenai kelompok itu saja. Kriteria perhitungan analisis statistik deskriptif ini meliputi pengukuran pemusatan seperti rata-rata data (mean), median atau nilai tengah, dan modus (nilai yang banyak muncul (Howell, 1982).

\section{Hasil Penelitian dan Pembahasan}

Pengambilan data pada penelitian ini dilaksanakan selama 21 hari dan didapatkan 655 data responden. Kemudian dilakukan penyortiran data hingga didapatkan 634 data yang valid. Tabel 1 menyajikan hasil pengolahan data deskriptif pengguna ojek online di KPY.

Tabel 1. Hasil Analisis Deskriptif Sosial Demografi Pengguna Ojek Online

\begin{tabular}{l} 
Pengguna Ojek Online \\
\cline { 2 - 2 } Hasil Survei \\
\cline { 2 - 3 } \\
\hline
\end{tabular}

Jenis

\begin{tabular}{|c|c|c|}
\hline & \multicolumn{2}{|c|}{ Hasil Survei } \\
\hline & Respon & Persen \\
\hline \multicolumn{3}{|l|}{ Kelamin } \\
\hline Pria & 272 & $43 \%$ \\
\hline Wanita & 362 & $57 \%$ \\
\hline$n$ & 634 & $100 \%$ \\
\hline \multicolumn{3}{|l|}{ Usia } \\
\hline 14-19 & 92 & $15 \%$ \\
\hline $20-24$ & 493 & $78 \%$ \\
\hline $25-29$ & 32 & $5 \%$ \\
\hline$>30$ & 17 & $3 \%$ \\
\hline$n$ & 634 & $100 \%$ \\
\hline \multicolumn{3}{|l|}{ Domisili } \\
\hline $\begin{array}{l}\text { Prov. DIY } \\
\text { Luar Prov. }\end{array}$ & 180 & $28 \%$ \\
\hline DIY & 454 & $72 \%$ \\
\hline$n$ & 634 & $100 \%$ \\
\hline \multicolumn{3}{|c|}{ Pendidikan } \\
\hline $\begin{array}{l}\text { SMA } \\
\text { Perguruan }\end{array}$ & 36 & $6 \%$ \\
\hline Tinggi & 598 & $94 \%$ \\
\hline$n$ & 634 & $100 \%$ \\
\hline \multicolumn{3}{|c|}{ Pendapatan } \\
\hline$<$ Rp 1juta & 226 & $36 \%$ \\
\hline 1-2juta & 209 & $33 \%$ \\
\hline $\begin{array}{l}\text { 2-3juta } \\
3-5 \text { juta } \\
5 \text {-7juta }\end{array}$ & $\begin{array}{l}99 \\
41 \\
30\end{array}$ & $\begin{array}{c}16 \% \\
6 \% \\
5 \%\end{array}$ \\
\hline$>7$ juta & 29 & $5 \%$ \\
\hline$n$ & 634 & $100 \%$ \\
\hline
\end{tabular}

$\begin{array}{lll}\begin{array}{l}\text { Ketersediaan } \\ \text { sepeda } \\ \text { motor }\end{array} & & \\ \text { Ada } & 502 & 79 \% \\ \text { tidak ada } & 132 & 21 \% \\ n & 634 & 100 \%\end{array}$

Berdasarkan Tabel 1, perbandingan jenis kelamin diunggulkan oleh responden perempuan dengan persentase sebesar 57\% sedangkan responden laki-laki 43\%. Kemudian untuk usia responden didominasi oleh responden yang berusia 20-24 tahun $(78 \%)$ dengan pendidikan rata-rata pendidikan tinggi strata 1 . Hal ini sejalan dengan studi yang berbasis di Amerika Serikat dan Kanada menemukan bahwa transportasi online lebih banyak digunakan oleh orang-orang yang relatif muda, Profil Pengguna, Tujuan ... - 63 
terpelajar dan berfinansial cukup (Clewlow \& Mishra, 2017; Dias dkk, 2019; Conway dkk, 2018; Grahn dkk, 2020; Sikder, 2019; Young \& Farber, 2019). Berdasarkan data Badan Pusat Statistik, Provinsi DIY memiliki 110 perguruan tinggi yang terletak di Kabupaten Sleman dan Kabupaten Bantul dengan pembagian 4 Perguruan Tinggi Negeri serta 106 Perguruan Tinggi Swasta. Hal ini mendorong banyaknya pelajar pendatang yang akan menetap di DIY dalam kurun waktu tertentu. Sejalan dengan kondisi tersebut, pada Tabel 1 menunjukkan persentase daerah asal responden dicenderungi oleh luar provinsi DIY sebanyak $72 \%$ dan rata-rata pendapatan yang dimiliki kisaran kurang dari satu sampai dua juta rupiah.

Sebagian besar responden didominasi oleh mahasiswa perguruan tinggi sehingga klasifikasi pendapatan mayoritas berada pada $<1$ juta-2juta rupiah. Sedangkan untuk kepemilikan sepeda motor cukup tinggi, sekitar 79\% responden memiliki sepeda motor yang juga merupakan pengguna ojek online. Sehingga dapat menjadi usulan penelitian lanjutan pengaruh kehadiran ojek online terhadap kepemilikan sepeda motor.

Tabel 2 menggambarkan persentase penggunaan ojek online pada beberapa tujuan dan kondisi. Pertanyaan survei ini ditujukan kepada pengguna ojek online dengan memberikan tujuh destinasi/kondisi yang dapat mereka pertimbangkan terhadap potensi penggunaan ojek online. Responden menilai menggunakan skala lima dengan indikator seberapa sering mereka menggunakan ojek online pada kondisi tersebut.

Hasil yang ditampilkan pada Tabel 2 menunjukkan bahwa frekuensi paling tinggi untuk menggunakan jasa ojek online adalah dengan tujuan perjalanan menuju fasilitas umum seperti bandara/stasiun/terminal atau simpul transportasi lainnya. Hal ini dapat disebabkan karena pengguna ojek online memilih moda tersebut sebagai first mile sehingga tidak membutuhkan biaya parkir (seperti pada Tabel 3) atau operasional lainnya. Sedangkan pergi untuk berbelanja menggunakan jasa ojek online memiliki skor terkecil, hal ini disebabkan karena berbelanja lebih nyaman dengan menggunakan kendaraan pribadi, khususnya kendaraan roda empat yang dapat memuat lebih banyak barang untuk diangkut. Selebihnya bepergian saat macet, pergi ke suatu daerah yang tidak memiliki kendaraan umum, pergi ke suatu tempat yang sebelumnya tidak pernah dikunjungi, pergi saat tergesa-gesa, pergi ke bekerja/sekolah serta pergi untuk melakukan sosial skornya hanya rata-rata tidak menunjukkan tingkat frekuensi yang tinggi.

Pada Tabel 3 dapat dilihat beberapa faktor yang mempengaruhi penggunaan ojek online. Hasil menunjukkan bahwa beberapa variabel memberikan pengaruh terhadap penggunaan ojek online. Apabila diurutkan dari nilai Mean tertinggi, faktor hubungan pengemudi dengan penumpang yang ramah, fasilitas teknologi yang tinggi, serta sistem rating kepada driver berpengaruh besar pada pemilihan menggunakan ojek online di Yogyakarta. Hal Budaya penduduk di Yogyakarta yang ramah dan santun dapat menjadi faktor pendukung sehingga driver ojek online di kota ini dinilai ramah. Selain itu, berdasarkan hasil penilaian responden pun aplikasi layanan ojek online ini memiliki utilitas yang tinggi. Hal tersebut sejalan dengan penelitian yang dilakukan oleh Nirmala \& Surveyandini, (2019) yang menunjukkan bahwa penggunaan ojek online didominasi oleh faktor kemudahan, faktor keamanan, dan faktor efisiensi.

Kemudian faktor kepercayaan brand, tidak memerlukan membayar parkir, pembayaran cashless, driver sebagai mitra, transportasi publik yang belum memadai, akses untuk melakukan transit sementara, serta waktu tempuh lebih singkat menjadi faktor yang cukup berpengaruh pada penggunaan ojek online. Rata-rata nilai mean yang didapatkan dari beberapa faktor tersebut mencapai nilai 3,8 yang berarti bahwa faktor-faktor tersebut cukup memberikan dampak kepada penggunaan ojek online di KPY. Hal ini serupa dengan penelitian yang dilakukan Dawes 
(2013)terkait faktor pendorong orang menggunakan jasa transportasi online di Amerika Serikat. Selain itu, menurut penelitian yang dilakukan oleh (Tumuwe dkk., 2018) menyatakan bahwa penggunaan ojek online di kalangan mahasiswa disebabkan oleh kemudahan akses yang ditawarkan.

Sedangkan faktor tidak memiliki kendaraan dan tidak dapat mengendarai sepeda motor memiliki nilai mean yang paling kecil. Hal ini berarti bahwa pengguna ojek online menilai tidak setuju dengan faktor tersebut, secara tidak langsung ini pun berarti bahwa mayoritas responden menilai dirinya memiliki sepeda motor dan dapat mengendarai kendaraan. Sehingga disimpulkan bahwa mayoritas pengguna ojek adalah pengguna yang memiliki sepeda motor dan dapat mengendarai sepeda motor. Maka dapat menjadi usulan penelitian lanjutan terkait hubungan antara kepemilikan sepeda motor dengan minat dan frekuensi penggunaan sepeda motor.

\section{Simpulan}

Hasil penelitian ini menunjukkan bahwa berdasarkan data sosial demografi, pengguna ojek online di Yogyakarta didominasi oleh jenis kelamin wanita, pengguna berusia muda, berpendidikan, dan perantau. Akan tetapi pada penelitian ini tidak ditinjau seberapa besar pengaruh yag diberikan dari data sosial demografi terhadap penggunaan ojek online. selain itu, ditinjau dari tujuan perjalanan menggunakan ojek online, pergi dari/menuju simpul transportasi menunjukkan nilai paling besar. Hal ini disebabkan adanya pembatasan serta preferensi pengguna yang tidak ingin membayar parkir maka akan menggunakan ojek online menuju pada destinasi tersebut.

Pada penelitian ini juga didapatkan beberapa faktor yang sangat tinggi mendorong masyarakat KPY untuk menggunakan ojek online adalah pengemudi yang ramah, fasilitas teknologi yang tinggi, serta sistem rating kepada driver. Akan tetapi pada penelitian ini tidak diukur tingkat pengaruh variabel tersebut terhadap penggunaan ojek online, maka saran untuk penelitian selanjutnya adalah mengukur pengaruh variabel sosial demografi dan faktor pendorong terhadap frekuensi penggunaan jasa ojek online 
Tabel 2. Hasil Analisis Deskriptif Tujuan Perjalanan Menggunakan Ojek Online

\begin{tabular}{|c|c|c|c|c|c|c|c|}
\hline & \multicolumn{4}{|c|}{ Persentase } & & \multicolumn{2}{|c|}{ likert scale } \\
\hline & 1 & 2 & 3 & 4 & 5 & Mean & Std. \\
\hline Menuju Bandara/Stasiun/Terminal & $5,17 \%$ & $14,83 \%$ & $29,00 \%$ & $30,17 \%$ & $20,83 \%$ & 3,47 & 1,13 \\
\hline Pergi saat macet & $16,83 \%$ & $23,17 \%$ & $29,17 \%$ & $23,00 \%$ & $7,83 \%$ & 2,82 & 1,19 \\
\hline Pergi ke/dari suatu daerah yang tidak memiliki bus kota & $21,83 \%$ & $14,33 \%$ & $21,83 \%$ & $29,00 \%$ & $13,00 \%$ & 2,97 & 1,35 \\
\hline Pergi ke suatu tempat yang belum pernah dikunjungi sebelumnya & $15,50 \%$ & $15,67 \%$ & $26,50 \%$ & $27,67 \%$ & $14,67 \%$ & 3,10 & 1,28 \\
\hline Pergi saat tergesa-gesa & $15,17 \%$ & $20,67 \%$ & $22,00 \%$ & $26,50 \%$ & $15,67 \%$ & 3,07 & 1,31 \\
\hline Pergi berbelanja & $32,67 \%$ & $24,83 \%$ & $24,33 \%$ & $11,17 \%$ & $7,00 \%$ & 2,35 & 1,24 \\
\hline Pergi ke sekolah/kantor & $15,17 \%$ & $22,50 \%$ & $28,17 \%$ & $18,50 \%$ & $15,67 \%$ & 2,97 & 1,28 \\
\hline Pergi melakukan aktivitsas social (makan restaurant, mengunjungi rumah teman atau saudara) & $18,50 \%$ & $22,83 \%$ & $31,33 \%$ & $18,67 \%$ & $8,67 \%$ & 2,76 & 1,20 \\
\hline
\end{tabular}

Tabel 3. Hasil Analisis Deskriptif Variabel Faktor Pendorong Menggunakan Ojek Online

\begin{tabular}{|c|c|c|c|c|c|c|c|}
\hline & \multicolumn{5}{|c|}{ Persentase } & \multicolumn{2}{|c|}{ likert scale } \\
\hline & 1 & 2 & 3 & 4 & 5 & Mean & Std. \\
\hline Pembayaran cashless (e-wallet) & $1,58 \%$ & $4,57 \%$ & $19,87 \%$ & $47,32 \%$ & $26,66 \%$ & 3,93 & 0,89 \\
\hline Driver adalah mitra, bukan karyawan & $3,00 \%$ & $6,31 \%$ & $19,40 \%$ & $48,74 \%$ & $22,56 \%$ & 3,82 & 0,95 \\
\hline Hubungan pengemudi dengan penumpang yang ramah & $0,16 \%$ & $0,32 \%$ & $10,41 \%$ & $53,94 \%$ & $35,17 \%$ & 4,24 & 0,65 \\
\hline Sistem rating kepada driver & $0,47 \%$ & $2,68 \%$ & $14,51 \%$ & $50,63 \%$ & $31,70 \%$ & 4,10 & 0,78 \\
\hline Akses untuk melakukan transit sementara & $0,32 \%$ & $7,26 \%$ & $24,29 \%$ & $47,48 \%$ & $20,66 \%$ & 3,81 & 0,86 \\
\hline Budaya perusahaan atau sikap CEOnya & $0,95 \%$ & $3,31 \%$ & $47,48 \%$ & $35,02 \%$ & $13,25 \%$ & 2,97 & 0,80 \\
\hline Kepercayaan brand & $0,32 \%$ & $1,42 \%$ & $20,35 \%$ & $55,36 \%$ & $22,56 \%$ & 3,98 & 0,72 \\
\hline Fasilitas teknologi yang tinggi & $0,16 \%$ & $0,32 \%$ & $12,30 \%$ & $54,73 \%$ & $32,49 \%$ & 4,19 & 0,66 \\
\hline Tidak memerlukan membayar parkir & $0,79 \%$ & $9,15 \%$ & $16,88 \%$ & $38,17 \%$ & $35,02 \%$ & 3,97 & 0,98 \\
\hline Waktu tempuh yang lebih singkat & $0,47 \%$ & $5,52 \%$ & $30,60 \%$ & $43,06 \%$ & $20,35 \%$ & 3,77 & 0,85 \\
\hline Transportasi publik belum nyaman dan memadai & $1,42 \%$ & $9,46 \%$ & $21,14 \%$ & $42,11 \%$ & $25,87 \%$ & 3,82 & 0,97 \\
\hline Tidak memiliki kendaraan pribadi & $15,46 \%$ & $32,18 \%$ & $20,03 \%$ & $19,40 \%$ & $12,93 \%$ & 2,82 & 1,27 \\
\hline Tidak bisa mengendarai kendaraan & $30,44 \%$ & $33,75 \%$ & $15,14 \%$ & $11,67 \%$ & $8,99 \%$ & 2,35 & 1,27 \\
\hline
\end{tabular}




\section{Daftar Pustaka}

Andriani (2019). Online vs Konvensional: Keunggulan dan Konflik Antar Moda Transportasi di Kota Makassar. ETNOSLA: Jurnal Etnografi Indonesia, 2(2), 220.

Clewlow, R. R., \& Mishra, G. S. (2017). Disruptive Transportation: The Adoption, Utilization, and Impacts of Ride-Hailing in the United States. Genome.

Conway, M., Salon, D., \& King, D. (2018). Trends in Taxi Use and the Advent of Ridehailing, 1995-2017: Evidence from the US National Household Travel Survey. Urban Science, 2(3), 79. https://doi.org/10.3390/urbansci2030 079

Dias, F. F., Lavieri, P. S., Kim, T., Bhat, C. R., \& Pendyala, R. M. (2019). Fusing Multiple Sources of Data to Understand Ride-Hailing Use. Transportation Research Record, 2673(6), 214-224.

https://doi.org/10.1177/03611981198 41031

Grahn, R., Harper, C. D., Hendrickson, C., Qian, Z., \& Matthews, H. S. (2020).

Socioeconomic and usage characteristics of transportation network company (TNC) riders. Transportation, 47(6), 3047-3067. https://doi.org/10.1007/s11116-01909989-3

Howell. 1982. Statistical Methods For Psychology. New York: Duxbury Press. Irawan, M. Z., Belgiawan, P. F., Joewono, T. B., \& Simanjuntak, N. I. M. (2020). Do motorcycle-based ride-hailing apps threaten bus ridership? A hybrid choice modeling approach with latent variables. Public Transport, 12(1), 207231. https://doi.org/10.1007/s12469019-00217-w
Metcalfe, G., Warburg, J. (2012) A Policy agenda for the sharing economy. The Urbanist

Nirmala, N., \& Surveyandini, M. (2019). Faktor Penentu Pemilihan Jasa Transportasi Online Pada Masyarakat Banyumas. Sustainable Competitive Advantage ..., 9(339). Retrieved from http://jp.feb.unsoed.ac.id/index.php/ sca-1/article/view/1422

Sikder, S. (2019). Who Uses Ride-Hailing Services in the United States? Transportation Research Record. https://doi.org/10.1177/03611981198 59302

Silver, N., Fischer-Baum, R. (2015). Public Transit Should Be Uber's New Best Friend. FiveThirtyEight.

Suryoatmono, B. (2007). Kursus Statistika Dasar. Jakarta.

Tang, B. J., Li, X. Y., Yu, B., \& Wei, Y. M. (2020). How app-based ride-hailing services influence travel behavior: An empirical study from China.

International Journal of Sustainable Transportation, 14(7), 554-568. https://doi.org/10.1080/15568318.20 19.1584932

Tumuwe, R., Damis, M., \& Mulianti, T. (2018). Pengguna ojek online di kalangan mahasiswa Universitas Sam Ratulangi Manado. Jurnal Holistik, (21), 1-19.

Young, M., \& Farber, S. (2019). The who, why, and when of Uber and other ride-hailing trips: An examination of a large sample household travel survey. Transportation Research Part A: Policy and Practice, 119 (December 2018), 383392. https://doi.org/10.1016/j.tra.2018.11. 018 